\title{
Primary Risk of Hypertension in Women with Age 45 - 54 Years
}

\author{
Dewi Puspito Sari, Dwi Sutiningsih \\ Diponegoro University Semarang, Indonesia \\ sari.puspito.dp@gmail.com
}

\begin{abstract}
Hypertension is the silent killer, one of the main risk factors for heart attack and stroke. Based on Riskesdas data in 2018 the prevalence of hypertension blood pressure measurements in Indonesia increased by $8.3 \%$, from $25.8 \%$ (in 2013) to $34.1 \%$ (in 2018). The prevalence of hypertension in Jambi Province based on the results of the 2013 Riskesdas was quite high at $24.6 \%$. In Sarolangun Regency primary hypertension was second only to ARI, which was $16.3 \%$. But the study of the characteristics of patients with primary hypertension in Sarolangun District is still limited. The purpose of this study was to determine the characteristics of patients with primary hypertension, especially the age and sex of patients in Sarolangun District in 2016. The method of this study was an observational descriptive study, with a case control study design. The sampling technique uses total sampling. The results of this study were that the characteristics of primary hypertension sufferers in Sarolangun District in 2016 were the highest in the 45-54 year age group of 2,073 people $(29,6 \%)$, with a female sex of 3,568 people $(51 \%)$. Women in Sarolangun District have a higher risk for hypertension.
\end{abstract}

Keywords: Hypertension, Primary Hypertension, Gender, Sarolangun Regency, Age 


\section{BACKGROUND}

Lifestyle changes are currently very influential on human health. One of the effects of lifestyle changes is the emergence of degenerative diseases. One type of degenerative disease is hypertension (Thaariq Fahriza, 2014). A person is said to suffer from hypertension when systolic pressure $>140 \mathrm{mmHg}$ and diastolic pressure $>90 \mathrm{mmHg}$ (Indonesia, 2013). Hypertension is a non-communicable disease that is still a health problem, hypertension is often referred to as the silent killer. In Indonesia hypertension has a high risk, the prevalence of Indonesian hypertension is 25.8\% (Indonesia, 2013).

Based on various studies have found several risk factors that often cause hypertension. One of them is an unhealthy lifestyle, for example, high salt consumption, excessive food, obesity, stress, drinking alcohol and smoking, lack of exercise, high-fat foods, ready-to-eat foods that contain lots of protein fat, and high in salt but low food fiber (Rasmaliah, 2004). Prolonged blood pressure increases can cause damage to body organs such as the kidneys can cause kidney failure, the heart can cause coronary heart disease and disorders in the brain so that it can cause strokes. This situation can occur if it is not detected early and has adequate treatment (Widarta et al., 2018).

In particular, the prevalence of hypertension in Jambi province based on the results of the 2013 risk education was $24.6 \%$, although it was below the prevalence of hypertension in Indonesia but the figure was quite high (Indonesia, 2013). Sarolangun Regency is one of the Regencies in Jambi Province with a significant incidence of hypertension.

Based on the health profile of Sarolangun district in 2016 hypertension is a disease that ranks second after ISPA, which is equal to $16.3 \%$ (Sarolangun, 2016). Here is a table of the 10 biggest diseases in Sarolangun District in 2016:

Table 1. Table 10 of the biggest diseases in 2016

\begin{tabular}{clcc}
\hline No & Type of Disease & Amount & Percentage $(\%)$ \\
\hline 1 & ISPA & 24.962 & 39.9 \\
\hline 2 & Primary Hypertension (essential) & 10.176 & 16.3 \\
\hline 3 & Dyspepsia & 7.959 & 12.7 \\
\hline 4 & Diarrhea & 6.493 & 10.4 \\
\hline 5 & Myalgia & 3.729 & 6.0 \\
\hline 6 & Fever that does not know why & 3.584 & 5.7 \\
\hline 7 & Influenza & 2.972 & 4.8 \\
\hline 8 & Dental Caries & 1.770 & 2.8 \\
\hline 9 & Asma & 1.242 & 2.0 \\
\hline 10 & Contact Dermatitis & 1.229 & 2.0 \\
\hline & Total & 62.523 & 100 \\
\hline
\end{tabular}

Source: Sarolangun District Health Office

Based on table.1, the type of hypertension that many people in Sarolangun Regency experience is primary hypertension (essential). Some of the main causes in the case of $90 \%$ of primary hypertension cannot be ascertained, however the risk factors often associated with primary hypertension such as heredity are more common in men, age and race, overweight, and high alcohol consumption (Jain, 2011). In addition to several factors above essential hypertension are also influenced by life style factors, there is a relationship between 


\section{STRADA Jurnal Ilmiah Kesehatan}

DOI: $10.30994 /$ sjik.v8i2.200

ISSN: 2252-3847 (print); 2614-350X (online)

Vol.8 No.2. November 2019. Page.123-128

high salt consumption with an increase in blood pressure, so that several other risk factors that affect hypertension such as diabetes, obesity, stress, excessive alcohol consumption, lack of exercise, and high consumption of potassium, magnesium and calcium intake (Jain, 2011). Primary hypertension is hypertension whose cause is unknown, although it is associated with a combination of lifestyle factors such as lack of movement and diet. Occurs in about $90 \%$ of people with hypertension (Indonesia, 2014).

According to a study conducted by Bagus (2012) regarding "Profile of Hypertensive Patients in Jombang General Hospital Period January-December 2011", with a sample of 337 respondents with hypertension, the highest number was 61 years old $(38.5 \%)$, female $(52.6 \%$ ), level of education up to (47.2\%), occupation of housewives (37.1\%), main complaints of shortness of breath (29.9\%), primary hypertension (96.2\%), hypertension degree $2(53.8 \%)$, there is no history of hypertension in his family (75.6\%) (Saputra, 2012).

Based on information from the Sarolangun District Health Office, 2016 still has limitations in providing data on the characteristics of primary hypertensive patients in Sarolangun District in 2016. The purpose of this study was to determine the characteristics of primary hypertensive patients in Sarolangun Regency in 2016 based on age group and gender. The benefit of this research is to be able to provide information to medical personnel about the characteristics of patients and the community so that the community immediately conducts an early examination so that the quality of health in the community becomes good.

\section{OBJECTIVE}

This study aimed to determine the characteristics of patients with primary hypertension, especially the age and sex of patients in Sarolangun District in 2016.

\section{METHODS}

The type of research used was descriptive observational with a case study design study with primary hypertension data sources in Sarolangun District in 2016 to become data used as reference material for counseling medical personnel, so that it is expected to reduce the risk of primary hypertension in the community, and can be used as a source or source data for the next study.

The population in this study were all the number of new primary hypertension cases in Sarolangun District health care facilities in 2016. The study samples were primary hypertensive patients who met the inclusion and exclusion criteria who were hospitalized in health service facilities in Sarolangun District in 2016. The inclusion criteria were hypertensive patients primary who are currently hospitalized in health service facilities in Sarolangun District in 2016.

The exclusion criteria were primary hypertensive patients who were undergoing outpatient care in Sarolangun District in 2016. The sampling technique in this study used all data recorded in health facilities in Sarolangun District taken. The instrument used in this study was secondary data from medical records of patients with primary hypertension in the health service facilities of Sarolangun Regency in 2016

\section{RESULTS}

Based on the results of research taken from medical records of hypertensive patients hospitalized in Sarolangun District health care facilities in 2016, 6,989 people were diagnosed with primary hypertension. From the samples that have been obtained are then described in table form. 


\section{Description of Characteristics of Hypertension Patients by Age Group}

Data on hypertensive patients based on age in Sarolangun Regency in 2016 are presented in table 2.

Table 2. Description of Characteristics of Patients with Primary Age Hypertension

\begin{tabular}{ccc}
\hline Age Group & Frequency & Percentage $(\%)$ \\
\hline $15-19$ & 23 & 0.4 \\
\hline $20-44$ & 1027 & 14.8 \\
\hline $45-54$ & 2073 & 29.6 \\
\hline $55-59$ & 1578 & 22.5 \\
\hline $60-69$ & 1428 & 20.4 \\
\hline $70+$ & 860 & 12.3 \\
\hline Total & 6989 & 100 \\
\hline
\end{tabular}

Based on table 2 above shows that the highest age classification in the $45-54$ age group is 2,073 people (29.6\%).

Description of Characteristics of Hypertensive Patients Based on Gender

Data on patients with primary hypertension based on sex in Sarolangun Regency in 2016 are presented in table 3.

Table 3. Description of Characteristics of Hypertensive Patients Based on Gender

\begin{tabular}{ccc}
\hline Age Frequency & Frequency & Percentage (\%) \\
\hline Male & 3422 & 49 \\
\hline female & 3568 & 51 \\
\hline Total & 6990 & 100 \\
\hline
\end{tabular}

\section{DISCUSSION}

Gender is closely related to the occurrence of hypertension where women are higher when a woman experiences menopause (Anggraini, 2012). This is in accordance with the Gracilaria (2017) study that one variable that has not been proven to influence hypertension in type $2 \mathrm{DM}$ patients is that male sex is not proven to be a risk factor because sex in all research subjects is homogeneous, where the number of female respondents is 3 times more than male respondents (Gracilaria Puspa Sari, 2017).

In age epidemiology studies included in the characteristics of people this is quite important because by knowing the age group we can know the description of the disease found with various frequency variations caused by age (Noor, 2008). Physiologically, the association of age with an increase in blood pressure is caused by changes in the elasticity of blood vessel walls over time, collagen proliferation, and calcium deposits associated with atherosclerosis. If followed by high blood pressure it can cause stiffness in the central arterial (Inggita Kusumastuty, 2016).

The incidence of hypertension has the potential to continue to increase as age increases, especially in the elderly, increasing age, the blood pressure will also increase (Rista Emiria 


\section{STRADA Jurnal Ilmiah Kesehatan}

DOI: $10.30994 /$ sjik.v8i2.200

ISSN: 2252-3847 (print); 2614-350X (online)

Vol.8 No.2. November 2019. Page.123-128

Afrida Apriany, 2012). After the age of 45 years, the arterial wall will be thickened because of the accumulation of collagen substances in the muscle layer, so that the blood vessels will gradually narrow and become stiff. Systolic blood pressure increases because the flexibility of large blood vessels decreases in the addition of age to the seventh decade while diastolic blood pressure increases until the fifth and sixth decades then settles or tends to decrease. Age factor also cannot be controlled, blood pressure when young with old age blood pressure will not be the same (Irianto, 2015 ).

Women who are more at risk of hypertension, especially during the pre-menopausal period, tend to have higher blood pressure than men, this is due to the presence of estrogen in a woman's body, which is a protector of cardiovascular disease. With increasing age, the estrogen hormone will experience a decrease especially after experiencing menopause (Armilawati, 2007). The estrogen hormone has a role as an antioxidant to prevent LDL oxidation and widen the heart's blood vessels so that the blood flow becomes smooth and the heart's oxygen supply is met (Khomsan, 2004).

The risk of hypertension will also increase after menopause which affects the decrease in the hormone estrogen which causes a decrease in the levels of High Density Lipoprotein (HDL) (Stevo Julius, 1991). There is a significant relationship between gender and the incidence of hypertension (Yuliarti, 2007). Low HDL cholesterol levels are a contributing factor in the occurrence of the atherosclerosis process. At pre-menopause women begin to lose little by little the hormone estrogen which protects blood vessels from damage. This continuous process causes the hormone estrogen to change its quantity according to the age of the woman naturally, which generally starts to occur in women aged 45-55 years.

\section{CONCLUSION}

Based on the research that has been done, it can be concluded that primary hypertension patients in Sarolangun Regency in 2016 occurred in women (51\%) with the age group 45$54(29.6 \%)$. Communities are expected to maintain their diet, lifestyle and conduct routine blood pressure checks in activities such as the Elderly Posyandu to be able to carry out early prevention so that it does not develop into more serious diseases. For the Sarolangun Health Office to carry out a comprehensive and routine monitoring and evaluation of NonCommunicable Diseases (PTM) programs so that the number of patients with primary hypertension does not increase.

\section{REFERENCES}

Anggraini. (2012). Gender Hypertension Patient, Bandung, PT Remaja Rosida Karya.

Armilawati. (2007). Hypertension and Risk Factors in Epidemiology Study, Makassar, Epidemiology Section of UNHAS FKM.

Gracilaria Puspa Sari, S., C., Tjokorda Gde Dalem Pemayun, Hadisaputro, S., \& Nugroho, H. (2017). Risk Factors that Influence Hypertension in Patients with Type II Diabetes Mellitus in Pati District Health Center. Journal of Epidemiology of Community Health (JEKK), 2, 54-61.

Indonesia, K. K. R. (2013). Results of the 2013 Riskesdas. 
Indonesia, P. D. D. I. K. K. R. (2014). Hypertension.

Inggita Kusumastuty, D., W., \& Wahyuni, E., S. (2016). Protein and Potassium Intake Associated with Decreasing Blood Pressure in Outpatient Hypertension. Indonesian Journal of Human Nutrition, 3 19-28.

Irianto, K. (2015). Understanding Various Diseases. Bandung. Alfabeta.

Jain, R. (2011). Alternative medicine to overcome blood pressure Jakarta PT. Gramedia Pustaka Utama.

Khomsan. (2004). Role of Food and Nutrition for Quality of Life. Jakarta. Grasindo.

Noor, N., N. (2008). Epidemiology Revised Edition. Jakarta. Penerbit Rineka Citra.

Rasmaliah, F., A., S., \& Jemadi. (2004). Epidemiological description of hypertension in the working area of Puskesmas in Pekan Labuhan District, Medan City, North Sumatra Province. University of Northern Sumatra.

Rista Emiria Afrida Apriany, T., M. (2012). Intake of protein, saturated fat, sodium, fiber and IMT is related to the blood pressure of hypertensive patients in RSUD Tugurejo Semarang. Journal of Nutrition College, 1, 21-29.

Saputra, B., R. (2012). Profile of hypertension patients in jombang hospital january december 2011 period.

Sarolangun, D., K. (2016). Profile of the Sarolangun Health Office in 2016.

Stevo Julius, M., Arbor, S., A., \& Mich. (1991). Clinical Implications of pathophysiologic changes in the midlife hypertensive patient American Heart Journal 122.

Thaariq Fahriza, S., \& Maryati. (2014). Effect of Herbal Therapy on Young Coconut Water on Decreasing Blood Pressure in Hypertension Patients in Addrejo Village, Bandar District, Batang Regency. Journal of Nursing and Midwifery Science (JIKK).

Widarta, I., W., Permana, I., D., \& Wiadnyani, A., A. (2018). Study of Time and Temperature of Avocado Leaves in Use as Herbal Tea. Journal of Food Technology Applications, 7, 55-61.

Yuliarti. (2007). Mayo Clinic Hypertension, Overcoming High Blood Pressure Mayo Clinic, Jakarta PT Intisari Mediatama. 